\title{
Profil Keterampilan Argumentasi Ilmiah Mahasiswa Pendidikan Biologi FKIP UNS pada Mata Kuliah Anatomi Tumbuhan
}

\author{
RIEZKY MAYA PROBOSARI ${ }^{1,2}$, MURNI RAMLI ${ }^{2}$, HARLITA $^{2}$, METI INDROWATI ${ }^{2}$, SAJIDAN ${ }^{1,2}$ \\ ${ }^{1}$ Program Studi S3 Pendidikan IPA FKIP Universitas Sebelas Maret, Jl. Ir. Sutami 36-A Surakarta, Indonesia \\ ${ }^{2}$ Program Studi Pendidikan Biologi FKIP Universitas Sebelas Maret, Jl. Ir. Sutami 36-A Surakarta, Indonesia \\ *email: riezkymaya@fkip.uns.ac.id
}

Manuscript received: 8 September 2015 Revision accepted: 15 Januari 2016

\begin{abstract}
Lemahnya argumentasi ilmiah mahasiswa dalam pembelajaran telah banyak menjadi perhatian, terutama dalam hal mengevaluasi dan mengkonstrak permasalahan dan solusinya. Penelitian ini bertujuan untuk mengetahui bagaimana profil keterampilan argumentasi ilmiah mahasiswa pada mata kuliah Anatomi Tumbuhan. Penelitian ini merupakan penelitian deskriptif untuk mendapatkan gambaran keterampilan argumentasi mahasiswa semester 3 di Prodi Pendidikan Biologi FKIP UNS melalui tugas tertulis yang diberikan. Penilaian argumentasi mahasiswa mengacu pada Toulmin's Argumentation Pattern (TAP) yang memuat komponen claim, evidence, reasoning dan rebuttal. Hasil penelitian menunjukkan bahwa kemampuan argumentasi ilmiah mahasiswa Pendidikan Biologi FKIP UNS masih tergolong rendah, dibuktikan dengan skor rerata claim sebesar 52\%, evidence sebesar $42 \%$, reasoning sebesar $15 \%$ dan rebuttal sebesar $10 \%$. Temuan ini akan dijadikan dasar bagi penelitian lanjutan mengenai model dan strategi pembelajaran inovatif yang dapat meningkatkan kemampuan argumentasi dan penalaran ilmiah terutama bagi calon guru biologi.
\end{abstract}

Keywords: argumentasi ilmiah, Toulmin's Argumentation Pattern, profil argumentasi

\section{LATAR BELAKANG}

Argumentasi merupakan bagian yang tidak bisa dipisahkan dari sains. Dalam praktek pembelajaran sains, argumentasi merupakan hal utama yang melandasi siswa dalam belajar bagaimana berpikir, bertindak dan berkomunikasi seperti seorang ilmuwan sejati. Iklim pembelajaran di dalam kelas turut menyumbang terjadinya komunikasi dalam bentuk adu argumentasi sebagai salah satu upaya untuk memvalidasi atau menyangkal pernyataan secara ilmiah. Pernyataan dalam hal ini tidak hanya sekedar memberikan pendapat atau gagasan, tetapi harus memberi alasan yang kuat untuk menjawab masalah. Sampson \& Scheilgh (2013) menyatakan bahwa yang dimaksud "alasan" harus menggambarkan dukungan dalam mengambil kesimpulan yang terutama didasarkan pada data yang diperoleh melalui penelitian.

Argumentasi ilmiah dalam sains mempunyai karakteristik yang khas, disbanding dengan argumentasi dalam konteks sehari-hari atau dalam bidang ilmu lain, terutama dalam keterkaitan antara pernyataan (claim), bukti (evidence) dan pertimbangannya (justification). "Pernyataan" merupakan pernyataan deskriptif yang menjawab masalah penelitian. "Bukti" mengacu pada pengukuran, pengamatan, atau hasil penelitian lain yang telah dikumpulkan, dianalisis, dan ditafsirkan. Komponen argumen pada akhirnya didapat dari pernyataan yang menjelaskan suatu fenomena disertai dengan bukti yang relevan dan didasarkan pada konsep atau asumsi yang melandasinya. Argumentasi ilmiah yang baik harus memenuhi kriteria empiris, teoritis dan analitis.

Kemampuan argumentasi menjadi salah satu tujuan utama pembelajaran sains karena siswa yang belajar sains harus mengetahui penjelasan ilmiah mengenai fenomena alam, menggunakannya untuk memecahkan masalah dan mampu memahami temuan lain yang mereka dapatkan. Selain itu mereka harus memahami karakter pengetahuan ilmiah yang selalu berkembang dari waktu ke waktu. Siswa yang mengerti sains secara utuh harus dapat memahami bahasa sains dan berpartisipasi secara aktif dalam kegiatan ilmiah seperti observasi dan argumentasi. Dalam kenyataannya masih banyak ditemui siswa yang mengalami kesulitan dalam hal ini sehingga pembelajaran harus mulai diarahkan untuk melibatkan para siswa dalam argumentasi ilmiah sebagai bagian dari sains.

Pembelajaran sains yang melibatkan argumentasi ilmiah tidak terjadi secara alami, namun harus direncanakan dengan seksama. Fokus dan model pembelajaran harus disesuaikan dan guru harus mampu mengarahkan siswa bagaimana membangun dan mendukung pengetahuan melalui argumen dan menilai serta menanggapi pernyataan atau argumentasi yang diajukan oleh orang lain. Permasalahan utama dalam hal ini adalah tidak semua guru mampu mengakomodir dan melaksanakan pembelajaran sains yang seperti ini. Hasil wawancara dengan beberapa guru biologi menunjukkan bahwa mereka memang belum memberdayakan kemampuan argumentasi dalam pembelajarannya karena merasa tidak mampu merancang pembelajaran karena keterbatasan sarana prasarana dan waktu. Membelajarkan siswa untuk berargumen nampaknya belum banyak diberdayakan, padahal Jiménez-Aleixandre \& Erduran (2007) mengemukakan bahwa argumentasi merupakan solusi untuk hampir semua masalah dalam pendidikan sains, di satu sisi membantu siswa mempelajari hal-hal yang sulit dipelajari misalnya dalam mengevaluasi bukti, 
dan di sisi lain berpotensi membantu guru memahami dan mendukung proses pembelajaran di kelas sains.

Berbagai teknik pembelajaran telah dikembangkan untuk meningkatkan penalaran dan kemampuan argumentasi siswa, antara lain dengan membimbing dan mengarahkan diskusi yang terutama diarahkan untuk meningkatkan penalaran secara kolaboratif (Macagno, Mayweg-Paus \& Kuhn, 2015). Konflik kognitif timbul dimanfaatkan untuk menstimulasi argumentasi siswa, baik yang menguatkan, mengevaluasi, mempertanyakan maupun menentang pernyataan yang dibuat sebelumnya. Untuk mencapai tujuan ini, guru harus merancang pembelajaran yang memberikan siswa kesempatan untuk belajar bagaimana menjelaskan data, menilai relevansi atau kecukupan bukti, mendukung pernyataan, menanggapi pertanyaan atau adu pendapat dan merevisi pernyataan berdasarkan umpan balik atau bukti baru yang didapatkan. Dengan kata lain guru berusaha semaksimal mungkin membantu siswa belajar dan mengadopsi kriteria yang sama yang digunakan oleh ilmuwan sejati dalam mendapatkan pengetahuan ilmiah (Schleigh, Bosse \& Lee, 2011; Clark, et.al, 2007; Zohar, 2007).

Penilaian kualitas argumentasi mengacu pada Toulmin's Argument Pattern (TAP). TAP dianggap mampu meningkatkan kualitas argumentasi di kelas melalui kegiatan mencari, menanggapi perbedaan dan mengambil sikap sehingga komunikasi ilmiah dalam kelas lebih efektif dan meminimalkan miskonsepsi siswa (Konstantinidou \& Macagno, 2013). Toulmin (2003) mengatakan bahwa suatu argumen didapatkan dari serangkaian kalimat yang saling berhubungan dan berdasarkan suatu pernyataan yang diyakini kebenarannya, yaitu claim (C), dengan data (D) yang sudah teruji, dan terhubung melalui warrant (W) dan diperkuat dengan backings (B). Argumen ditentang dalam rebuttals $(\mathrm{R})$, atau counter-arguments yang menyajikan fakta yang berlawanan dengan data, warrant maupun backings sehingga membuktikan bahwa pernyataan tersebut benar. Qualifiers (Q) menunjukkan kekuatan simpulan yang didapatkan dan bagaimana hal itu bisa diaplikasikan dan valid.

Secara teoritis, kemampuan argumentasi yang kompleks meliputi semua unsur dalam TAP, tapi dalam prakteknya didapatkan bahwa banyak siswa mengalami kesulitan untuk mencapai semua aspek tersebut secara utuh. Kesiapan dan kemampuan guru dalam mengarahkan pembelajaran sains yang argumentatif menjadi salah satu kunci bagi keberhasilan siswa dalam berargumentasi, sehingga sebelum terjun ke lapangan, calon guru harus diberikan bekal yang cukup mengenai argumentasi dalam pembelajaran. Sebagai calon guru biologi, mahasiswa di Prodi Pendidikan Biologi Universitas Sebelas Maret juga harus membiasakan diri melakukan komunikasi ilmiah yang argumentatif, baik secara lisan melalui diskusi dan presentasi, maupun secara tertulis, dalam bentuk paper atau artikel ilmiah. Sebelum merancang model dan strategi pembelajaran yang sesuai untuk meningkatkan kemampuan argumentasi ilmiah, perlu diketahui bagaimana kemampuan awal mahasiswa dalam membuat dan mempresentasikan tulisan argumentatif yang mereka buat, sehingga diperoleh pemetaan aspek argumentasi mana yang paling membutuhkan perhatian dan bagaimana mengatasinya.

Penelitian ini dilakukan untuk mengetahui profil keterampilan argumentasi ilmiah mahasiswa pada mata kuliah Anatomi Tumbuhan secara riil, baik dalam bentuk lisan maupun tulisan. Mata kuliah ini selain melibatkan hands on activity di laboratorium, juga didominasi dengan tagihan tulisan ilmiah terutama untuk materi yang sulit dipraktikumkan. Mahasiswa juga harus mempresentasikan hasil pekerjaan yang sudah dilakukannya, terutama untuk mendukung hasil pengamatan laboratoris. Hasil akhir penelitian ini diharapkan bisa menjadi landasan pemerdayaan keterampilan argumentasi ilmiah terutama bagi calon guru biologi melalui model dan strategi pembelajaran yang tepat.

\section{METODE}

Penelitian dilakukan pada 69 mahasiswa semester 4 Tahun Ajaran 2014/2015 Program Studi Pendidikan Biologi Universitas Sebelas Maret Surakarta yang mengambil mata kuliah Anatomi Tumbuhan dengan menggunakan pendekatan penelitian deskriptif, untuk mendapatkan profil keterampilan argumentasi mahasiswa. Peta keterampilan argumentasi didapatkan dengan menelaah hasil tugas proyek yang diberikan kepada mahasiswa. Proyek diberikan dalam bentuk tulisan argumentatif ilmiah mengenai adaptasi morfo-anatomi tumbuhan di berbagai habitat. Penilaian argumentative writing mengacu pada Toulmin's Argument Pattern (TAP) dengan elemen elemen argument yang meliputi claim, evidence, reasoning, dan rebuttal (Toulmin, 2003 ; Acar and Patton, 2012).

\section{HASIL DAN PEMBAHASAN}

Kemampuan merumuskan dan mengevaluasi argumen telah banyak diakui menjadi dasar keterampilan berpikir yang baik dan menjadi salah satu tujuan pendidikan sains. Konstantinidou \& Macagno (2013) menyatakan bahwa siswa yang mendapatkan pembelajaran sains harus mampu menyajikan pernyataan yang akurat, mengkomunikasikannya kepada yang lain secara meyakinkan, menanggapi argumen orang lain dan membandingkan berbagai argumentasi secara logis. Argumentasi ilmiah berperan untuk menyajikan dan mengatasi kesenjangan antara gagasan dan bukti melalui pernyataan yang valid. Lebih lanjut Berland dan Hammer (2012) menyebutkan bahwa seseorang mempunyai kemampuan argumentasi melalui pencapaiannya dalam memahami fenomena yang dialaminya, mengemukakan pemahamannya dan meyakinkan orang lain agar menerima gagasannya. Untuk mencapai hal itu, mereka harus mengkonstrak dan mendukung pernyataan dengan bukti dan penalarannya, mempertanyakan yang mempertahankan ide dan jika perlu merevisi pernyataannya atau pernyataan yang diajukan orang lain. Hal ini sayangnya tidak semua terjadi pada mahasiswa yang membuat tugas proyek mengenai adaptasi morfo-anatomi tumbuhan di berbagai habitat. 
Hasil penilaian kemampuan argumentatif tulis maupun lisan pada konsep anatomi tumbuhan disajikan sebagai berikut :

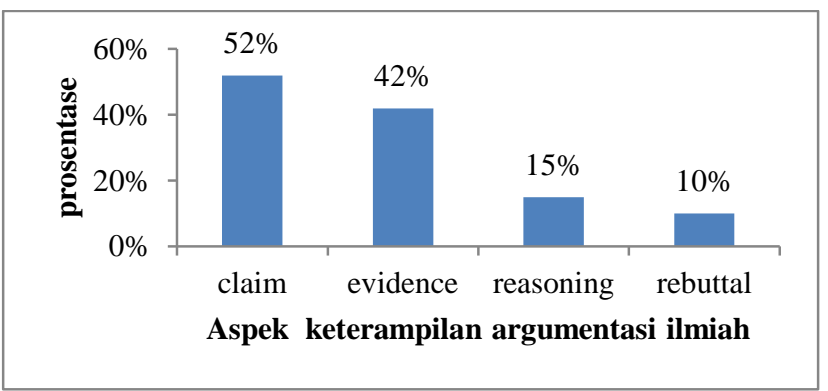

Gambar 1. Profil keterampilan argumentasi ilmiah

Tabel di atas menunjukkan bahwa mahasiswa masih mengalami kesulitan dalam melakukan argumentasi ilmiah, dalam hal ini argumentasi ilmiah dalam bentuk tulisan ilmiah. Hasil wawancara dengan mahasiswa menunjukkan bahwa kesulitan terbesar dalam membuat esai adalah bagaimana mereka mengambil informasi kunci dalam suatu sumber, kemudian menghubungkannya dengan fakta dan data yang dimiliki. Sumber pustaka yang

Uraian

Nulembo nucifera merupakan tanaman akuatik dikotil tetapi memiliki morfologi seperti monokotil (C). Anatomi khas dari daun lotus adalah terdapat kristal drusen. Kristal drusen merupakan benda ergastik yang berbentuk padat, merupakan kristal kalium oksalat yang berbentuk menyerupai bintang. Lebih special lagi bahwa pada setiap sel dari lotus terdapat "only one single drusen" atau hanya terdapat satu drusen setiap selnya (E).

Pada beberapa jurnal maupun artikel dikatakan bahwa adaptasi anatomis tumbuhan hidrofit yaitu reduksi jaringan pelindung berupa epidermis (C) , epidermis beralih fungsi bukan sebagai pelindung tetapi berfungsi untuk penyerapan gas dan nutrient langsung karena dinding selulosa dan kutikulanya tipis (Re). Tidak punya stomata (tumbuhan hidrofit tenggelam) pertukaran gas langsung melalui dinding sel. Pada sel epidermis Potamogeton memiliki kloroplas hal ini didukung pada buku karena juga menyatakan hal tersebut pula yang menjadi salah satu bentuk adaptasinya (E). Diafragma atau ruang kosong ini banyak ditemukan di batang dan daun tanaman air. Selain hipoksia, factor pembatas lain dari tanaman yang terendam adalah kelarutan rendah karbondioksida. Namun untuk mengatasi kondisi ini, banyak tanaman terendam termasuk potamogeton beradaptasi untuk meningkatkan gas yang masuk. Untuk Potamogeton polygonus, diafragma juga penting dalam pembesaran area untuk fiksasi CO2, karena mereka memiliki kloroplas (Re) Didukung dengan referensi lain yang menyatakan bahwa rongga terisi udara terdapat pada batang dan daun hidrofit. Rongga tersebut merupakan ruang antarsel yang terdapat diseluruh daun dan batang, seperti pada Potamogeton dan Eichornia , rongga -rongga tersebut dipisahkan oleh sekat pemisah tipis yang terdiri dari 1-2 lapisan sel berkloroplas. Pemisah atau diafragma itupun terdapat pada rongga yang memanjang.

Tanaman mahoni merupakan tanaman bioindikator akumulasi logam yang menunjukkan adaptasi anatomis pada daun dengan adanya polutan (C). Pada dasarnya, tanaman yang tumbuh di daerah tercemar polutan, pasti akan menyerap gas-gas dan zat-zat lain ke dalam mesofil daunnya pada saat proses asimilasi $\mathrm{CO} 2$ dalam proses fotosintesis. Pembatasan dalam pembukaan lubang atau celah stomata, dengan kutikula daun yang memberikan tahanan yang sangat tinggi akan mampu menanggulangi efek buruk akumulasi dari polutan yang masuk ke

\section{Kategori Argumentasi \\ $\mathbf{C}=$ Claim, $\mathbf{E}=$ evidence, $\mathbf{R e}=$ reasoning, $\mathbf{R b}=$ Rebuttal}

Lemah, memuat claim tetapi tidak ada reasoning yang melandasi pernyataan, data dan evidence tidak menceritakan dirujuk dari mana, rebuttal tidak ada.

Rendah, memuat claim tetapi ada reasoning belum menjelaskan secara rinci mengapa epidermis tereduksi dan bagaimana perbandingannya dengan tumbuhan lain, evidence banyak tapi tidak dijelaskan sumbernya, rebuttal tidak ada.

Sedang, memuat claim, reasoning ada dan cukup lengkap tapi kurang sistematik, evidence jelas, rebuttal tidak ada. 
dalam sel mesofil. Jika polutan tersebut masuk ke sel mesofil, maka pengaruh utamanya akan terletak pada tingkat molekuler atau tingkat ultra-struktural ( $\mathrm{Re})$. Polutan tersebut dapat menyebabkan perubahan dalam respon perubahan dan jumlah stomata, kerusakan struktur kloroplas, penurunan kandungan klorofil, luas permukaan daun, fiksasi $\mathrm{CO} 2$, serta sistem transport elektron fotosintetiknya yang dapat menurunkan hasil akhir fotosintesis dan akan menghambat pertumbuhannya $(\mathrm{Re})$. Seiring dengan naiknya konsentrasi logam berat timbal $(\mathrm{Pb})$, maka maka hasil akhir fotosintesis tanaman akan menurun, yang ditunjukkan pada terhambatnya pertumbuhan, serta terjadi kecenderungan penurunan kandungan klorofil, luas permukaan daun, jumlah stomata, dan perubahan kandungan dan penurunan kadar klorofil terkait dengan rusaknya struktur kloroplas. Beberapa sumber pustaka (Ewais, 1997; Xiong, 1997; Kastori et.al, 1998; Fargaśová, 2001 dalam Olivares 2003) telah menyatakan mengenai kaitan antara konsentrasi $\mathrm{Pb}$ dengan perubahan kandungan klorofil total pada daun, dimana kandungan klorofil total akan mengalami penurunan sejalan dengan meningkatnya kadar $\mathrm{Pb}(\mathrm{E})$. Pada lingkungan yang rendah kadar emisi gas buangnya, yaitu jarak antara 100 - 200 meter, pertumbuhan daun dan organorgan tanaman mahoni tidak mengalami gangguan secara signifikan. Reduksi pada beberapa organ dan proses fisiologinya berkaitan erat dengan tingkat polusi tempat tumbuhnya (Agrawal, 2001), semakin dekat jarak tumbuh tanaman dengan sumber kadar gas buang kendaraan bermotor, maka klorofil yang mengalami degradasi akan semakin besar, sehingga kadarnya menjadi semakin rendah $(\mathrm{Re})$. Adaptasi anatomi berupa penurunan respon dan jumlah stomata sehingga terjadi pengurangan dan kelainan dalam fiksasi karbon dioksida, kerusakan struktur kloroplas sehingga kandungan klorofil mengalami pengurangan, pengurangan luas permukaan daun untuk mengefektifkan fotosintesis dan meminimalisir akumulasi $\mathrm{Pb}$, mengalami penurunan hasil akhir fotosintesis sehingga pertumbuhannya menjadi terhambat, mengalami kelainan pada organ generatifnya yaitu pada gametofit jantannya yang prematur dan dapat mengalami kemandulan (E).

Penilaian argumentasi mahasiswa juga dilakukan pada saat mereka melakukan presentasi. Hasil pengamatan menunjukkan bahwa counter-argument masih belum banyak terjadi. Pertanyaan yang diajukan umumnya masih bersifat teoritis yang bisa dijawab berdasarkan ingatan, padahal dialog argumentasi sebaiknya dimulai dengan fenomena riil yang terjadi di alam dan memicu adanya perbedaan sudut pandang dalam menanggapinya.

Hasil temuan penelitian menunjukkan fakta baru bahwa argumentasi ilmiah harus mulai dibudayakan dalam pembelajaran. Merubah paradigm lama mengenai kecenderungan menghindari konfrontasi dalam argumentasi atau dikenal sebagai counter-argument menjadi argumentasi ilmiah yang sebenarnya memerlukan waktu yang tidak sebentar. Hal yang perlu diperhatikan adalah membawa esensi argumentasi dalam pembelajaran sains membutuhkan adanya rancangan dan strategi yang tepat. Crowell\&Kuhn (2013) telah membuktikan bahwa setelah dilakukan intervensi melalui pembiasaan dialog argumentative dalam pembelajaran, didapatkan bahwa keterampilan argumentasi siswa akhirnya meningkat, dan hal itu terjadi secara merata, baik untuk siswa dengan kemampuan akademis atas maupun bawah dan bahkan setelah tiga tahun hamper tidak terlihat perbedaan antara siswa yang kemampuan argumentasi awalnya rendah dengan siswa dengan kemampuan tinggi.

Mengidentifikasi argumentasi sebagai tujuan pendidikan merupakan salah satu langkah dalam memaknai hakekat sains. Langkah selanjutnya yang perlu diambil adalah bagaimana merancang dan melaksanakan pembelajaran yang mampu mengoptimalkan keterampilan argumentasi siswa, sekaligus mengintegrasikannya dalam kurikulum. Penelitian ini selanjutnya diharapkan bisa menjadi fondasi awal dalam rangka memasukkan argumentasi dalam kurikulum pembelajaran sains.

\section{KESIMPULAN}

Hasil penelitian menunjukkan bahwa kemampuan argumentasi ilmiah mahasiswa Pendidikan Biologi FKIP UNS masih tergolong rendah, dibuktikan dengan skor rerata claim sebesar $52 \%$, evidence sebesar $42 \%$, reasoning sebesar $15 \%$ dan rebuttal sebesar $10 \%$. Temuan ini akan dijadikan dasar bagi penelitian lanjutan mengenai model dan strategi pembelajaran inovatif yang dapat meningkatkan kemampuan argumentasi dan penalaran ilmiah terutama bagi calon guru biologi.

\section{DAFTAR PUSTAKA}

Acar, O. \& Patton, B. R. (2012). Argumentation and Formal Reasoning Skills in An Argumentation-based Guided Inquiry Course. In Procedia: Social and Behavioral Sciences (46). pp. $4756-4760$.

Berland, L.K. \& Hammer, D. (2012). Framing for Scientific Argumentation. Journal of Research in Science Teaching. 49 (1): 68-94.

Clark, D., Stegmann, K., Weinberger, A., Menekse, M., \& Erkens, G. (2007). Technology-enhanced learning environments to 
upport students' argumentation. In S. Erduran \& M.P. Jimenez Aleixandre (Eds). Argumentation in Science Education: Perspectives from Classroom-Based Research. Netherlands: Springer. pp. 217-243.

Jaber, L.Z. \& Hammer, D. (2016). Learning to Feel Like a Scientist. Science Education, (100):189-220.

Konstantinidou, A. \& Macagno, F. (2013). Understanding Students' Reasoning: Argumentation Schemes as an Interpretation Method in Science Education. Science \& Education. 22 (5). Pp. 1069-1087.

Crowell, A. \& Kuhn, D. (2014). Developing Dialogic Argumentation Skills: A 3-year Intervention Study. Journal of Cognition and Development. 15 (2): 363-381.

Jiménez-Aleixandre, M.P., \& Erduran, S. (2007). Argumentation in Science Education: An Overview. In Erduran, S. \& Jiménez-Aleixandre, M.P.(Eds). Argumentation in Science Education: Perspectives from Classroom-Based Research. Netherlands : Springer. Pp. $3-27$.
Macagno, F., Mayweg-Paus, E., \& Kuhn, D. (2015). Argumentation Theory in Education Studies: Coding and Improving Students' Argumentative Strategies. Topoi 34:523-537.

Sampson, V. \& Scheilgh, S. (2013). Scientific argumentation in biology : 30 classroom activities. United States of America : National Science Teachers Association.

Schleigh, S. P., Bossè, M. J., \& Lee, T. (2011). Redefining curriculum integration and professional development: Inservice teachers as agents of change. Current Issues in Education, 14 (3).

Zohar, A. (2007). Science Teacher Education and Professional Development in Argumentation. In S. Erduran \& M.P. Jimenez Aleixandre (Eds). Argumentation in Science Education: Perspectives from Classroom-Based Research. Netherlands: Springer. Science Teacher Education and Professional Development in Argumentation. Pp. 245-268.

Toulmin, S.E. (2003). The Uses of Argument. United Kingdom: Cambridge University Press. pp. 89-95, 114-118. 